https://nv.nltu.edu.ua

https://doi.org/10.15421/40280711

$@ \bowtie$ Correspondence author

Article received 3.09.2018 p.

Article accepted 26.09.2018 p.

I. S. Neyko

удк $630 * 232.13$

ihor_neyko@ukr.net

I. С. Нейко, О. В. Колчанова

ДП "Вінницька лісова науково-дослідна станція" УкрНДІЛГА, м. Вінниця, Україна

\title{
АДАПТИВНІСТЬ ТА ОСОБЛИВОСТІ РОСТУ СОРТІВ ТОПОЛІ В УМОВАХ ПОДІЛЛЯ
}

Досліджено особливості укорінення та росту сортів тополі. Всього вивчено 10 сортів тополі української та зарубіжної селекції, для яких характерна різна інтенсивність росту в умовах Харківщини. Використано живці таких культиварів: 'Версія', 'Волосистоплода', 'Константа', 'Львівська', 'Новоберлінська', 'Ноктюрн', 'Перспективна', 'Російська', 'Слава України', 'Стрілоподібна'. Оцінено вплив умов середовища (типів лісорослинних умов) на здатність до укорінення та ріст сортів тополі. Для оцінювання взаємодії сорт - середовище розраховано індекси: ековаленсія Вріске, показник стабільності Шукля, ранжування генотипів за стійкістю до середовища, показник стабільності Канга. Комплексна оцінка перспективності сорту включала показники укорінення, енергії росту та адаптивності до умов середовища. За результатами досліджень виявлено, що найоптимальнішими для вирощування тополі $\epsilon$ умови сирого груду $\left(\mathrm{D}_{4}\right)$. Найвищою енергією росту на найбільш зволожених грунтах відрізнялися сорти 'Львівська', 'Новоберлінська' та 'Версія'. В умовах мінімального зволоження за висотою переважали культивари: 'Волосистоплода', 'Львівська' і 'Константа'. За комплексною оцінкою щодо здатності до укорінення, інтенсивності росту та адаптивності до умов середовища найперспективнішими $є$ сорти 'Львівська' та 'Новоберлінська'. Сорт 'Волосистоплода' доцільно використовувати як один із найстійкіших у посушливих умовах.

Ключові слова: культивар; тип лісорослинних умов; укорінення; ріст.

Вступ. Упродовж останніх десятиліть як в Україні, так і за рубежем значну увагу приділяють вирощуванню швидкорослих деревних порід, зокрема, тополі (Bohdanov, 1936; Albenskii, 1946; Iablokov, 1956; Tsarev, 1985; Fuchylo, 2008; Sven, 2008; Debryniuk \& Solovii, 2012; Torosova et al., 2015; Fuchylo at al., 2017). Важливість вирощування тополі набула світового маштабу (FAO UN, 1958). За результатами тривалих досліджень у Європі встановлено високу продуктивність та стійкість таких сортів, як: 'Polargo', 'Alberto', 'Degrosso' та 'Sanosol' (FAO UN, 1958; Sven, 2008). Значного поширення набув сорт 'Koster', який виявився найпродуктивнішим у багатьох європейських країнах (Sven, 2008).

В Україні у XX ст. під керівництвом Н. В. Старової проведено значний обсяг робіт із міжвидової гібридизації тополь (Torosova et al., 2015). Зокрема, було відібрано понад 600 перспективних сортів та гібридів. Проте, багато культиварів мали незадовільний ріст у певних грунтовогідрологічних умовах, тому не набули широкого впровадження у практику (Patlay, Zhurova \& Haida, 1999; Torosova et al., 2015). На сьогодні у сортовипробуванні перебуває більше, ніж 30 сортів і гібридів (Тоrosova et al., 2015).

За результатами останніх досліджень в Україні виявлено перевагу деяких сортів тополі у регіонах Східного Лісостепу, Київського Полісся, Південного Степу, Центрального Поділля (Torosova et al., 2015, Fuchylo, 2008, Fuchylo at al., 2017, Neyko et. al., 2017). В умовах Західного Лісостепу найвищою енергією росту відріз- нялися сорти 'Тронко', 'Стрілоподібна', 'Дружба' та гібрид тополі 'Канадська × Бальзамічна' (Fuchylo at al., 2017). Поряд із цим більшість дослідів закладено в однотипних грунтово-гідрологічних умовах із обмеженою кількістю культиварів. Це не дає змоги дослідити широкий спектр сортів в умовах зміни середовища та виявити найперспективніші для певних регіонів.

Мета роботи - дослідити адаптивну здатність та енергію росту сортів тополі у різноманітних умовах середовища та виявити найперспективніші для Подільського регіону.

Об'єкт дослідження - сорти тополі української та зарубіжної селекції, особливості їх укорінення та росту у різних типах лісорослинних умов.

Методика проведення дослідження. У 2017 р. ми здійснили дослідження щодо укорінення та росту 10 сортів тополі, отриманих із Харківського національного аграрного університету (ХНАУ), які мали різну продуктивність. Досліджено такі сорти: 'Версія', 'Волосистоплода', 'Константа', 'Львівська', 'Новоберлінська', 'Ноктюрн', 'Перспективна', 'Російська', 'Слава України', 'Стрілоподібна'. Досліди закладено в умовах ДП "Вінницька лісова науково-дослідна станція" у чотирьох типах лісу: свіжому грабово-дубовому сугруді $\left(\mathrm{C}_{2}\right.$-гД), свіжій грабовій діброві ( $\mathrm{D}_{2}$-гД), сируватому чорновільховому сугруді ( $\mathrm{C}_{3-4}$-Влч), сирому чорновільховому груді (D4-Влч). Ділянка свіжого груду була у сільськогосподарському користуванні. Інші ділянки представлені свіжим зрубом 2017 p.

\section{Інформація про авторів:}

Нейко Ігор Степанович, ст. наук. співробітник, заступник директора. Email: ihor_neyko@ukr.net Колчанова Олена Вікторівна, мол. наук. співробітник. Email: olena.kolchanova@gmail.com

Цитування за ДСтУ: Нейко І. С., Колчанова О. В. Адаптивність та особливості росту сортів тополі в умовах Поділля. Науковий вісник НЛТУ України. 2018, т. 28, № 7. С. 53-56.

Citation APA: Neyko, I. S., \& Kolchanova, O. V. (2018). Adaptability and peculiarities of poplar varieties growth in conditions of the Podillya region. Scientific Bulletin of UNFU, 28(7), 53-56. https://doi.org/10.15421/40280711 
Наприкінці вегетаційного періоду здійснили обліки успішності укорінення сортів. Також виконано вимірювання висот. Отримані дані опрацювали за допомогою пакетів програми R-статистика. Для оцінювання взаємодії сорт - середовище розраховано такі показники: ековаленсія Bріске (Wricke, 1962), показник стабільності Шукля (Shukla, 1972), ранжування генотипів за стійкістю до середовища (Becker \& Leon, 1988), показник стабільності Канга (Pham \& Kang, 1988). Для оцінювання істотності різниці середніх значень між сортами застосовано критерій достовірності (адитивності) Тьюкі (Tukey, 1949).

Результати дослідження та їх обговорення. Вегетаційний період 2017 р. характеризувався недостатнім рівнем зволоженості у весняний період, що призвело до низької здатності до укорінення більшості сортів тополі (25,1\%) (табл. 1$)$.

Табл. 1. Загальна здатність до укорінення живців сортів тополі (\%) у розрізі типів лісу в умовах ДП "Вінницька ЛНДС"

\begin{tabular}{|c|c|c|c|c|c|}
\hline Сорт & $\mathrm{C}_{2}$-гД & $\mathrm{D}_{2}$-гД & $\mathrm{C}_{3-4}$-Влч & $\mathrm{D}_{4}$-Влч & Всього \\
\hline Версія & 0,0 & 5,0 & - & 3,3 & 1,9 \\
\hline Волосистоплода & 20,0 & 18,3 & 30,0 & 43,3 & 30,0 \\
\hline Константа & 15,0 & 16,7 & 23,3 & 30,0 & 18,1 \\
\hline Львівська & 28,3 & 26,7 & 27,8 & 86,7 & 39,0 \\
\hline Новоберлінська & 23,3 & 36,7 & 30,0 & 86,7 & 38,6 \\
\hline Ноктюрн & 18,3 & 18,3 & 16,7 & 26,7 & 20,0 \\
\hline Перспективна & 30,0 & 18,3 & 24,4 & 96,7 & 34,8 \\
\hline Російська & 1,7 & 6,7 & 5,6 & 0,0 & 3,8 \\
\hline Слава України & 3,4 & 3,3 & 7,8 & 23,3 & 7,1 \\
\hline Стрілоподібна & 23,4 & - & 20,0 & 43,3 & 34,0 \\
\hline Всього & 16,3 & 16,7 & 18,6 & 44,0 & 25,1 \\
\hline
\end{tabular}

Найвищим ризогенезом характеризувалися сорти: 'Львівська', 'Новоберлінська', 'Перспективна' (35-39 \%). Незадовільним укоріненням відрізнялися сорти: 'Версія', 'Російська' та 'Слава України' (2-7 \%). Щодо типів лісу найкраще укорінення (44 \%) було в умовах максимальної зволоженості $\left(\mathrm{D}_{4}\right.$-Влч). За найнижчого рівня зволоження $\left(\mathrm{C}_{2}\right.$-гД) здатність до укорінення культиварів була мінімальною (16,3\%).

У сирому груді найвищою приживлюваністю відрізнялися сорти: 'Перспективна' (96,7 \%), 'Львівська' та 'Новоберлінська' (по 86,7 \%). Зі зниженням зволоженості та родючості грунту у сируватому сугруді дещо вищим укоріненням характеризувалися сорти 'Волосистоплода' (45,0 \%), 'Стрілоподібна' (40,0 \%) та 'Львівська' $(38,4 \%)$. В умовах свіжого груду найвища приживлюваність була у сортів 'Новоберлінська' (36,7\%) та 'Львівська' (26,7%). Сорти 'Львівська' та 'Перспективна' мали вищу здатність до укорінення в умовах свіжого сугруду.

Найбільший вплив рівня зволоженості на укорінення живців відзначено у сорту 'Перспективна'. Достатньо високе реагування на зростання зволоженості характерне також для сортів 'Львівська' та 'Новоберлінська'. Стабільна здатність до укорінення була у таких сортів, як: 'Російська' та 'Версія'.

Загальний аналіз росту сортів тополі за висотою в усіх умовах середовища показав значну їх мінливість. Найвища мінливість сортів ( $v=39,4 \%$ ) характерна для лісорослинних умов із максимальним рівнем зволоженості $\left(\mathrm{D}_{4}\right)$. У менш вологих лісорослинних умовах $\left(\mathrm{D}_{2}\right.$ $\mathrm{C}_{2}$ ) мінливість сортів за висотою істотно знижувалася ( $v=13,0 \%$ та 22,6 \% відповідно). Найвищим рівнем мін- ливості за висотою характеризувалися такі сорти, як 'Новоберлінська', та 'Львівська' ( $v=34,8 \% \quad v=32,1 \%)$. Високий ступінь також був у таких сортів, як 'Перспективна', 'Стрілоподібна' та 'Константа' ( $v=29,7$ \%, 29,5 \%, 27,4 \% відповідно). Найнижчий рівень мінливості був у сортів 'Російська', 'Ноктюрн' та 'Версія' ( $v=12,3 \%$, $\nu=16,9 \%, \nu=18,0 \%$ ).

Середня висота сортів тополь в усіх типах лісу становила 25,6 см. Найвища продуктивність культиварів була в умовах сирого чорновільхового груду (39,4 см). У цьому ж типі лісорослинних умов максимальні значення висоти однорічних пагонів тополь становили 140 см. Близькими значеннями $(21,6-22,3$ см) за середнім показником висоти характеризувалися сорти в умовах свіжого сугруду та вологого груду. Максимальні значення висоти сортів тополь у цих умовах становили 90-95 см. Найнижча середня висота (14,4 см) була у свіжому груді. У цьому типі лісорослинних умов максимальні значення висоти тополь становили 44 см.

В умовах вологого груду найвищою продуктивністю відрізнялися такі сорти: 'Новоберлінська', 'Перспективна' та 'Львівська' (44-46 см). Максимальні значення висоти цих сортів у цих лісорослинних умовах становили 80-140 см. У свіжому груді найвища продуктивність була у культиварів 'Волосистоплода' (22 см) та 'Перспективна' (18,6 см). У свіжому сугруді переважання за висотою відзначено у такого сорту, як 'Волосистоплода' (43 см). Значно нижчими були сорти: 'Львівська' (28 см) та 'Константа' (24 см). У сируватому сугруді за висотою переважали сорти 'Волосистоплода', 'Новоберлінська' та 'Стрілоподібна' (27-28 см). За розрахованим показником різниці середніх значень (Tukey's honestly significant difference test, 1949) встановлено достовірну різницю між сортами в усіх типах лісу, окрім сортів 'Львівська' - 'Ноктюрн' та 'Новоберлінська'- 'Ноктюрн'.

Особливості росту культиварів у розрізі типів лісорослинних умов наведено на рисунку.

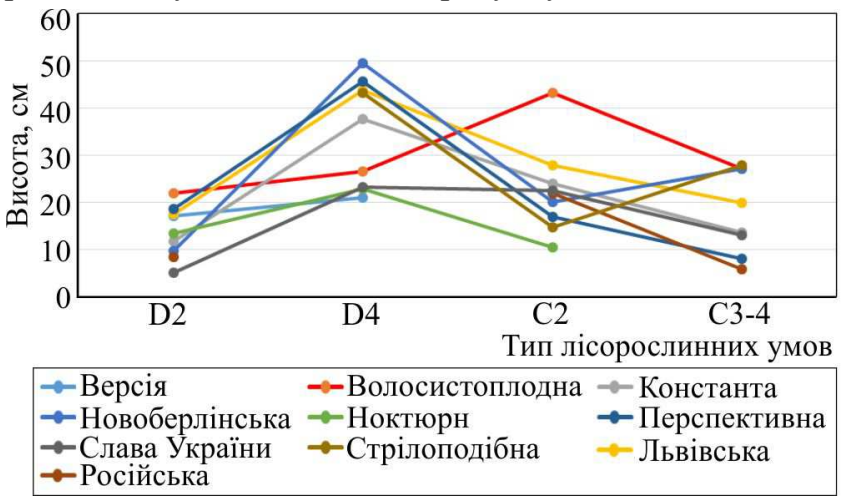

Рисунок. Особливості росту сортів тополі у розрізі лісорослинних умов

За даними рисунка більшість сортів позитивно відреагували на зростання зволоженості умов середовища. Винятком був сорт 'Волосистоплода', зростання продуктивності якого відбулося у більш засушливих умовах $\left(\mathrm{C}_{2}\right)$. Вкрай негативно на зниження зволоженості відреагували такі сорти, як "Новоберлінська" та "Перспективна". Ці сорти в умовах $\mathrm{D}_{4}$ мали найвищу середню висоту, а в умовах $\mathrm{C}_{2}-$ найнижчу. Відносною стабільністю відрізнявся сорт 'Львівська', який за високої енергії росту у більш зволожених лісорослинних умовах зберіг достатньо високу продуктивність за знижен- 
ня рівня зволоженості. Для аналізу реагування сорту на зміну умов середовища розраховано показники їх екологічної стабільності (табл. 2).

Табл. 2. Показники екологічної стабільності сортів тополі у різних умовах середовища

\begin{tabular}{|c|c|c|c|c|}
\hline \multirow{2}{*}{ Сорт } & \multicolumn{4}{|c|}{ Індекси стабільності сорту } \\
\cline { 2 - 5 } & $\begin{array}{c}\text { Wricke, } \\
1962\end{array}$ & $\begin{array}{c}\text { Shukla, } \\
1972\end{array}$ & $\begin{array}{c}\text { Becker and } \\
\text { Léon, 1988 }\end{array}$ & $\begin{array}{c}\text { Kang, } \\
1988\end{array}$ \\
\hline Версія & 1280,0865 & 9,50000 & 3 & 2 \\
\hline Волосистоплода & 3161,9237 & 25,00128 & 8 & 9 \\
\hline Константа & 248,1985 & $21,25,000$ & 7 & 8 \\
\hline Львівська & 98,8586 & 27,67414 & 9 & 10 \\
\hline Новоберлінська & 3324,7023 & 29,15110 & 10 & 11 \\
\hline Ноктюрн & 556,2048 & 12,25000 & 4 & 3 \\
\hline Перспективна & 1290,2823 & 18,41441 & 5 & 6 \\
\hline Російська & 2612,0380 & 7,37500 & 2 & 1 \\
\hline Слава України & 303,8979 & 6,37500 & 1 & 0 \\
\hline Стрілоподібна & 2258,9548 & 20,55468 & 6 & 7 \\
\hline
\end{tabular}

За даними табл. 3 значення показника ековаленсії (Wricke, 1962) було найвищим для сортів: 'Новоберліська', 'Волосистоплода' та 'Російська'. Водночас такі сорти, як 'Львівська', 'Ноктюрн' та 'Слава України' виявилися найменш адаптованими для умов середовища. Поряд із цим, за розрахованими іншими показниками (Shukla, 1972; Becker and Léon, 1988; Kang, 1988) значну перевагу мали сорти: 'Новоберлінська', 'Львівська', 'Волосистоплода'.

Табл. 3. Зведена таблиця перспективності сортів за здатністю до укорінення, енергісю росту за висотою та адаптивністю до умов середовища

\begin{tabular}{|c|c|c|c|c|c|}
\hline Сорт & $\begin{array}{c}\text { Пив- } \\
\text { жаніс- } \\
\text { баль }\end{array}$ & $\begin{array}{c}\text { Продук- } \\
\text { тив- } \\
\text { ність, } \\
\text { бал }\end{array}$ & $\begin{array}{c}\text { Ріст за } \\
\text { зниженні } \\
\text { зволожен- } \\
\text { ня, бал }\end{array}$ & $\begin{array}{c}\text { Ранг адап- } \\
\text { тивності } \\
\text { (Becker and } \\
\text { Léоn, 1988) }\end{array}$ & $\begin{array}{c}\text { За- } \\
\text { галь- } \\
\text { ний } \\
\text { бал }\end{array}$ \\
\hline Версія & 1 & 4 & 2 & 3 & 10 \\
\hline $\begin{array}{c}\text { Волосис- } \\
\text { топлода }\end{array}$ & 6 & 7 & 10 & 8 & 31 \\
\hline Константа & 4 & 6 & 8 & 7 & 25 \\
\hline Львівська & 10 & 9 & 9 & 9 & 37 \\
\hline $\begin{array}{c}\text { Новобер- } \\
\text { лінська }\end{array}$ & 9 & 10 & 6 & 10 & 35 \\
\hline Ноктюрн & 5 & 3 & 7 & 4 & 19 \\
\hline $\begin{array}{c}\text { Перспек- } \\
\text { тивна }\end{array}$ & 8 & 5 & 3 & 5 & 21 \\
\hline Російська & 2 & 2 & 4 & 2 & 10 \\
\hline $\begin{array}{c}\text { Слава } \\
\text { України }\end{array}$ & 3 & 1 & 1 & 1 & 6 \\
\hline $\begin{array}{c}\text { Стрілопо- } \\
\text { дібна }\end{array}$ & 7 & 8 & 5 & 6 & 26 \\
\hline
\end{tabular}

Із врахуванням показника укорінення, саме індекси стабільності та стійкості до середовища (Shukla, 1972; Becker \& Léon, 1988; Pham \& Kang, 1988) є найбільш інформативними та достовірними для оцінювання адаптивності сортів тополі у розрізі умов середовища. За цими індексами сорти 'Слава України', 'Російська' та 'Версія' є найменш адаптованими до змін середовища в умовах регіону. Враховуючи те, що сорти 'Новоберлінська' та 'Перспективна'вкрай негативно прореагували на зниження рівня зволоженості, адаптивнішим треба вважати сорт 'Львівська'. Водночас такий сорт, як 'Стрілоподібна' може бути найперспективнішим в умовах засух та зниження рівня зволоженості (зокрема в умовах кліматичних змін).

Загальна оцінка перспективності досліджуваних сортів включала їх ранжування за такими показниками, як: приживлюваність, продуктивність, здатність витримувати засушливі умови (зміна росту за висотою в умо- вах найменшого зволоження - $\mathrm{C}_{2}$ ), адаптивність до умов середовища (ранг адаптивності (Becker and Léon, 1988). Враховуючи те, що індекс Канга (Kang, 1988), Шукля (Shukla, 1972) та ранг адаптивності (Becker and Léon, 1988) є взаємопов'язані між собою, прийнято у розрахунок лише останній показник (Becker and Léon, 1988). Загальний бал перспективності сорту розраховано для типів лісорослинних умов (табл. 3). За даними цієї таблиці найперспективнішими в умовах регіону $\epsilon$ сорт 'Львівська' (37 балів). Значний потенціал також у таких сортів, як 'Новоберлінська'та 'Волосистоплода' (сумарний бал перспективності - 35 та 31). Найнижчий бал перспективності у сортів: 'Слава України', 'Російська' та 'Версія'.

Висновки. Лісорослинні умови Поділля є сприятливими для росту та розвитку більшості сортів тополі. Найпридатнішими для закладання плантацій в умовах є сирі типи місцезростання $\left(\mathrm{D}_{4}\right)$. Найперспективнішими для вирощування $є$ культивари 'Львівська' та 'Новоберлінська', які достатньо адаптовані для умов регіону та можуть бути використані для створення плантацій швидкорослих порід. Сорт 'Волосистоплода' доцільно використовувати як один із найстійкіших в умовах зниження зволоженості.

\section{Перелік використаних джерел}

Albenskii, A. V. (1946). Kultura topoley. Moscow: Gos. kn. izdatelstvo. [In Russian].

Becker, H. C., \& Leon, J. (1988). Stability analysis in plant breeding. Plant Breeding, 101(1), 13-15.

Bohdanov, P. L. (1936). Topolya i ih cultura. Leningrad: Goslestehizdat. [In Russian].

Debryniuk, Yu. M., \& Solovii, I. P. (2012). Plantatsiine lisovyroshchuvannia: ekoloho-ekonomichni, tekhnolohichni ta lisivnychi aspekty. [Forest plantations: environmental, economic, technological and silvicultural aspects]. Proceedings of the Forestry Academy of Sciences of Ukraine: Collection of Research Papers, 10, 48-54. [In Ukrainian].

FAO, UN (1958). Poplars in forestry and land use. Forestry and forest products studies, 12. FAO, UN, $511 \mathrm{p}$.

Fuchylo, Ya. D. (2008). Plantatsiine lisovyroshchuvannia v Ukraini: perspektyvy rozvytk. [The forest plantations in Ukraine: perspectives of development]. Proceedings of the Forestry Academy of Sciences of Ukraine: Collection of Research Papers, 6, 97-99. [In Ukrainian].

Fuchylo, Ya. D., Sbytna, M. V., et al. (2017). Growth and productivity of hybrid poplar plantanions in conditions of western forest-steppe of Ukraine. Scientific Bulletin of UNFU, 27(9), 43-47. https://doi.org/10.15421/40270909

Iablokov, A. S. (1956). Pyramydalnye topoly. [Pyramidal poplars]. Moscow-Leningrad, 320 p. [In Russian].

Kang, M. S., \& Pham, H. N. (1991). Simultaneous selection for high yielding and stable crop genotypes. Agron. J., 83, 161-165.

Neyko, I. S., Kolchanova, O. V., et. al. (2017). Characteristics of rooting and growth of poplar varieties using substance for moisture accumulation Terravet-100 in forest vegetation type of Vinnytsia region. Scientific Bulletin of UNFU, 27(10), 33-36. https://doi.org/10.15421/40271004

Patlay, I. M., Zhurova, P. T., \& Haida, Yu. I. (1999). Sortovyprobuvannia lisovykh porid v Ukraini. [Sort-testing of forest species in Ukraine]. Lisivnytstvo i ahrolisomelioratsiia. Selektsiya ta lisorozvedennia, 96, 3-9. [In Ukrainian].

Shukla, G. K. (1972). Some statistical aspects of partitioning genotype-environmental components of variability. Heredity, 29, 237-245. https://doi.org/10.1038/hdy.1972.87

Sven, M. G. de Vries. (2008). Beeding and slection of poplars in Netherlands.Treebreedex Activity. INRA, Orleans, 28 p. 
Torosova, L. O., Vysotska, N. Yu., Los, S. A., Orlovska, T. V., \& Zolotykh, I. V. (2015). Doslidzhennia predstavnykiv rodu Populus za morfolohichnymy oznakamy. [Studies of morphological characters for representatives of populous genus]. Lisivnytstvo i ahrolisomelioratsiia, 126, 148-157. [In Ukrainian].

Tsarev, A. P. (1985). Sortovedenye topolia. [Outputting of poplar varieties]. Voronezh: Izd-vo Voronezhskoho un-ta, 236 p. [In Russian].

Tsarev, A. P., Tsareva, R. P., \& Tsarev, V. A. (2010). Dynamyka sokhrannosty y produktyvnosty nastoiashchykh topolei pry ispyta- nii v uslovyiakh umerennoho klymata. [The time pattern of survival and productivity of Eupopulus tested in the temperate climatic belt]. Vestnyk-VOHyS, 14(1), 65-68. [In Russian].

Tukey, John (1949). Comparing Individual Means in the Analysis of Variance. $\quad$ Biometrics, $\quad 5(2), \quad 99-114$. https://doi.org/10.2307/3001913

Wricke, G. (1962). Evaluation Method for Recording Ecological Differences in Field Trials. Z Pflanzenzücht, 47, 92-96.

ГП "Виниинкая леснаи научно-исследовательская станция" УкрНиИЛ

И. С. Нейко, Е. В. Колчанова

\section{АДАПТИВНОСТЬ И ОСОБЕННОСТИ РОСТА СОРТОВ ТОПОЛЯ В УСЛОВИЯХ ПОДОЛЬЯ}

Исследованы особенности укоренения и роста сортов тополя. Всего изучено 10 сортов тополя украинской и зарубежной селекции, которые характеризовались разной интенсивностью роста в условиях Харьковской области. Использованы черенки следующих культиваров: 'Версия', 'Волосистоплодая', 'Константа', 'Львовская', 'Новоберлинская', 'Ноктюрн', 'Перспективная', 'Российская', 'Слава Украины', 'Стреловидная'. Оценено влияние условий среды (типов лесорастительных условий) на способность к укоренению и рост сортов тополя. Для оценки взаимодействия сорт - среда рассчитаны индексы: эковаленсия Вриске, показатель стабильности Шукля, ранжирование генотипов по устойчивости к среде, показатель стабильности Канга. Комплексная оценка перспективности сорта включала показатели укоренения, энергии роста и адаптивности к условиям среды. По результатам исследований выявлено, что наиболее оптимальными условиями для выращивания тополя есть условия сырого груда (D4). Наивысшей энергией роста в наиболее увлажненных почвах отличались сорта 'Львовская', 'Новоберлинская' и 'Версия'. В условиях минимального увлажнения по высоте преобладали культивары: 'Волосистоплодая", 'Львовская' и 'Константа'. По комплексной оценке за способностью к укоренению, интенсивностью роста и адаптивностью к условиям среды, наиболее перспективными являются сорта 'Львовская' и 'Новоберлинская'. Сорт 'Волосистоплодая' целесообразно использовать как один из самых устойчивых в засушливых условиях.

Ключевые слова: культивар; тип лесорастительных условий; укоренение; рост.

I. S. Neyko, O. V. Kolchanova

SE "Vinnitsa Forest Research Station", Vinnitsa, Ukraine

\section{ADAPTABILITY AND PECULIARITIES OF POPLAR VARIETIES GROWTH IN CONDITIONS OF THE PODILLYA REGION}

The features of poplar cultivars rooting and growth are carried out. We investigated survival, growth and adaptation of poplar varieties in Podillya Region (Central part of Ukraine). Ten poplar cultivars of Ukrainian and foreign breeding were studied. These cultivars had a different intensity of growth in the conditions of Kharkiv Region. We used the following poplar varieties: 'Versiya', 'Volosystoploda', 'Constanta', 'Lvivska', 'Novoberlinska', 'Noktyurn', 'Perspectyvna', 'Rosiyska', 'Slava Ukrainy', 'Strilopodibna'. It has been revealed that environmental conditions have a considerable impact on ability of poplar varieties to root and their growth. We used following indices: the environment-varieties interaction: Wricke's ecovalence (1962), Shukla's stability variance, (1972), the ranking of genotypes to environmental resistance (Becker and Léon, 1988), the Kang's yield stability (Kang, Pham 1991). Comprehensive evaluation of availability included indicators: rooting ability, growth intensity, and adaptability to environment conditions. We determined more intensive rooting of poplar varieties: 'Lvivska', 'Novoberlinska', 'Perspectyvna' (35-39\%). The best survival of poplar varieties was in condition of maximum humidification. The less rooting activities were in drain condition (16\%). In drain condition, best survival had 'Strilopodibna' cultivar. Increase of humidification had the most intensive impact on 'Perspectyvna'. The research results have found that sufficient moisture conditions (D4) are the most appropriate ones for growing poplar. The following poplar varieties demonstrated the highest growth: 'Lvivska', 'Novoberlinska' and 'Versiya'. The highest growth in minimal humidification conditions had the following varieties: 'Volosystoploda', 'Lvivska' and 'Constanta'. According to the comprehensive assessment of the rooting ability, growing and adaptability to the environment condition, the most availability is presented by the varieties of 'Lvivska' and 'Novoberlinska'. The variety of 'Volosystoploda' is advisable to use as one of the most stable in condition of reducing moisture.

Keywords: cultivar; type of forest environment conditions; rooting; growth. 